Article

\title{
Bio-Methane Production via Anaerobic Co-Digestion by Optimizing the Mixing Ratios of River Tamarind (Leucaena leucocephala) and Dolphin Fish (Coryphaena hippurus) Offal
}

\author{
Nikolai Holder ${ }^{1}{ }^{1}$, Marilaine Mota-Meira ${ }^{1}$, Jens Born ${ }^{2}$ and Sarah L. Sutrina ${ }^{1, *}$ \\ 1 Department of Biological and Chemical Sciences, Faculty of Science and Technology, The University of the \\ West Indies, Bridgetown 11000, Barbados; nikolai.holder@gmail.com (N.H.); \\ marilaine.mota-meira@cavehill.uwi.edu (M.M.-M.) \\ 2 Department of Mechanical Engineering, Process Engineering and Maritime Technologies, \\ Hochschule Flensburg, University of Applied Sciences, 24943 Flensburg, Germany; jens.e.born@gmail.com \\ * Correspondence: slsutrina@gmail.com
}

Received: 10 July 2020; Accepted: 30 July 2020; Published: 3 August 2020

\begin{abstract}
Fish offal and other high protein substrates are generally not suitable for anaerobic digestion because of the high levels of ammonia produced as a result of their biodegradation. In order to efficiently use these types of substrates to produce methane, co-digestion is used to balance the amounts of carbon and nitrogen in the feedstock. In this experiment an optimization procedure for maximizing the methane potential of fish offal, using river tamarind as the co-substrates was developed. Our experimental design tested the effects of substrate to substrate mixtures, as well as overall substrate to inoculum combinations, on the methane potentials. This was performed using batch style biochemical methane potential assays, which employed a methodology developed in our laboratory. The optimum of the 25 combinations tested was $50 \%$ fish offal to $50 \%$ river tamarind at a substrate to inoculum ratio of 0.03 , with a specific methane yield of $144 \pm 6 \mathrm{NmL} / \mathrm{gFM}$ $(330 \pm 14 \mathrm{NmL} / \mathrm{goDM})$. This gave much improvement when compared with the fish offal alone, which reached $63 \pm 4 \mathrm{NmL} / \mathrm{gFM}(317 \pm 20 \mathrm{NmL} / \mathrm{goDM})$ at maximum. These results indicate that with the correct mixture, rivertamarind is a suitable co-substrate for anaerobic co-digestion of fish offal.
\end{abstract}

Keywords: co-digestion; anaerobic digestion; biogas; biomethane; fish offal; river tamarind

\section{Introduction}

Anaerobic digestion is the biochemical process by which bioorganic degradable material, through a series of biochemical reactions mediated by a consortium of micro-organisms, is converted into biogas [1,2]. This biogas is comprised mainly of methane and carbon dioxide and can be used as a fuel. Anaerobic co-digestion is the mixing of two or more feedstocks in the anaerobic bioreactor in order to improve the efficiency of the anaerobic digestion process [3]. The advantage of this is that the drawbacks of single substrate digestion, such as unfavorable carbon-nitrogen $(\mathrm{C} / \mathrm{N})$ ratios, high ammonia content, high volatile acid production, or even inadequate amounts of a particular substrate can be overcome $[1,3,4]$. It has been noted that while the $\mathrm{C} / \mathrm{N}$ ratio is an important parameter for co-digestion, it is not the defining parameter, and there are several others which need to be controlled, such as $\mathrm{pH}$ and organic loads, for example [4]. A highly variable range of $\mathrm{C} / \mathrm{N}$ ratios has been reported as suitable for stable bioreactor performance, including ratios of 20 and 70, and also lower values, in the 6-9 range. 
Fish offal and other substrates which are high in protein are generally not favorable substrates for anaerobic digestion because of the biochemical breakdown products of their anaerobic degradation, ammonia [5]. Proteins are converted to amino acids during the hydrolysis stage, from which ammonia is released during the acidogenesis stage [6]. Intermediate molecules such as ammonia and volatile fatty acids have been shown to play a role in bioreactor destabilization if the levels are too high [5]. One way of managing this is maintaining low substrate to inoculum ratios to prevent bioreactor overload [1]. Another increasingly popular method is through the use of anaerobic co-digestion in which two or more substrates are mixed, in order to improve gas production efficiency $[1,3,5,7,8]$.

The fishing industry is a very large industry in various territories, and ways of managing fish offal are of extreme importance, especially for Small Island Developing States (SIDS). These usually have small land masses and as a result, waste management is of very high priority [9]. This study, conducted in Barbados, which has a very large fishing industry, investigates the use of river tamarind for co-digestion with the fish offal. The river tamarind is also of importance because it can be used as an energy cropand is indeed being considered for use as an energy crop in Barbados. Additionally, this information is beneficial to other SIDS and other territories within the tropical/subtropical regions of the world in which the river tamarind grows well and is most often found as wild shrubbery.

Aside from providing a possible solution to the management of fish offal waste, successful anaerobic digestion of the fish offal also produces a renewable source of energy in the form of biogas. This is also of significance to SIDS because most of these territories have little oil reserves and have to import fuel to meet their energy demands, which comes at a high cost.

The novelty of this work lies in the following:

(1) The main purpose of this study is to investigate if, by co-digestion with river tamarind, a combination can be developed that will allow the microbial consortium within the anaerobic digester to effectively utilize the fish offal. An experimental design was constructed which varied both the quantities of the substrates in combination with one another. For each combination, the combined substrate to inoculum ratio was also varied. The response for this experiment was the specific methane yield. This allowed a type of surface plot to be produced, in the form of a heat map that allows a reasonable determination of the most suitable conditions for co-digestion offish offal with river tamarind.

(2) There is no readily available literature investigating the potential of these two substrates for anaerobic co-digestion, nor for the river tamarind alone, increasing the novelty of the work. Specifically, the river tamarind has potential to be grown as an energy crop and using fish offal for biogas production is an excellent way of repurposing this waste.

(3) Our approach to the setup of a co-digestion biochemical methane potential test is very different from the traditional approach that is commonly used. This test uses a system which takes into account both the substrate to substrate and the combined substrate to inoculum ratios, and determines the optima for both to achieve maximal bioreactor efficiency.

\section{Materials and Methods}

\subsection{Determination of Physico-Chemical Characteristics of Substrates}

\subsubsection{Dry Matter and Organic Dry Matter}

The dry matter $(\mathrm{DM})$ and organic dry matter $(\mathrm{oDM})$ contents were determined using standard methods as outlined in the VDI-4630 [10]. The DM content was determined by measuring the mass of the sample after drying it at $100{ }^{\circ} \mathrm{C}$ for $24 \mathrm{~h}$. The oDM content was determined by heating the sample at $550^{\circ} \mathrm{C}$ in a muffle furnace for $2 \mathrm{~h}$ and subtracting the remaining mass (ash) from the dry matter. 


\subsubsection{Total Organic Carbon}

The total organic carbon levels were determined by the Walkley-Black procedure, adapted by D. L. Heanes, for spectrophotometric analysis [11,12]. A solution of sucrose $(4.754 \mathrm{~g})$ in $1 \mathrm{~L}$ of distilled water was prepared ( $1 \mathrm{~mL}$ of this solution is equivalent to $2 \mathrm{mg}$ of organic carbon) [11]. This solution was used to prepare a calibration curve (range 0-2000 $\mu$ g organic carbon) and $1 \mathrm{~mL}$ of sample was reacted with $1 \mathrm{~mL}$ of chromic acid. $1 \mathrm{~mL}$ of distilled water was added to a small mass of sample (varied with sample), and $1 \mathrm{~mL}$ of chromic acid was added. The samples were allowed to incubate at $90^{\circ} \mathrm{C}$ for $1.5 \mathrm{~h}$. The samples were allowed to cool and the absorbances read at $645 \mathrm{~nm}$. These data are listed in Table 1.

Table 1. Physico-Chemical Characteristics of Substrates ( $n=3 \pm \mathrm{SD})$.

\begin{tabular}{ccccccc}
\hline Substrate & $\begin{array}{c}\text { Dry Matter } \\
\text { (DM) } \\
\text { g/gFM }\end{array}$ & $\begin{array}{c}\text { Organic Dry } \\
\text { Matter (oDM) } \\
\text { g/gFM }\end{array}$ & $\begin{array}{c}\text { Ash } \\
\text { Content } \\
\text { g/gFM }\end{array}$ & $\begin{array}{c}\text { Total Organic } \\
\text { Carbon } \\
\text { (mgTOC/gFM) }\end{array}$ & $\begin{array}{c}\text { Nitrogen } \\
\text { Content } \\
\text { (g/gFM) }\end{array}$ & $\begin{array}{c}\text { TOC/oDM } \\
\text { Ratio }\end{array}$ \\
\hline $\begin{array}{c}\text { River Tamarind } \\
\text { (Leucaena leucocephala) }\end{array}$ & $0.473 \pm 0.008$ & $0.437 \pm 0.006$ & $0.035 \pm 0.002$ & $81.1 \pm 6.16$ & $6.71 \pm 2.94$ & 0.186 \\
\hline $\begin{array}{c}\text { Dolphin } \\
\text { (Coryphaena hippurus) }\end{array}$ & $0.216 \pm 0.005$ & $0.199 \pm 0.006$ & $0.017 \pm 0.002$ & $3.94 \pm 0.28$ & $28.01 \pm 8.07$ & 0.019 \\
\hline
\end{tabular}

\subsubsection{Nitrogen Content}

The nitrogen content was determined by assaying for the protein content using the salt/alkaline extraction method and Bradford assay [13]. For each substrate, $4 \mathrm{~g}$ of raw material was homogenized with $240 \mathrm{~mL}$ of $0.1 \mathrm{M} \mathrm{NaOH}$ in $3.5 \% \mathrm{NaCl}$ using a blender. The homogenates were incubated at $60^{\circ} \mathrm{C}$ for $90 \mathrm{~min}$ and then centrifuged at $4000 \times \mathrm{g}$ for $30 \mathrm{~min}$ at $4{ }^{\circ} \mathrm{C}$. The Bradford assay was then performed to determine the protein content using BSA as the protein standard. The protein content was then divided by a conversion factor of 6.25 (equivalent to $0.16 \mathrm{~g}$ nitrogen per gram of protein) to estimate the total nitrogen in the sample [13]. The carbon to nitrogen ratio was then determined by dividing the mass of organic carbon by the mass of nitrogen.

\subsection{Anaerobic Digestion Experiments}

The small scale bioreactor system described in a previous article was used for these tests [14]. The system consists of a set of $50 \mathrm{~mL}$ bioreactors, each holding a total of $25 \mathrm{~g}$ of material (inoculum and substrate). The bioreactor system was operated at mesophilic temperatures $\left(35^{\circ} \mathrm{C}\right)$ and the experiment was run for 30 days, in triplicate, with gas measurements taken periodically within this time frame. The temperature was maintained using a water bath incubator system. The water bath used was a Grant JB Series, Model 6204-29005, Grant Instruments, 29 Station Rd, Shepreth, Royston SG8, 6GB, UK.

\subsubsection{Substrate Collection and Preparation}

Wild river tamarind was harvested from a natural habitat on the southern part of the island. The leaves, branches and pods of the plant were collected, dried and blended. The fish (dolphin) offal was obtained from a local fish processing plant on the island. No additional treatment was done on the dolphin waste and it was already mulched from the fish processing process.

\subsubsection{Experimental Design}

We set the maximum mass of substrate to be added to the reactors at $5 \mathrm{~g}$, and selected $5 \mathrm{~g}(100 \%)$, $3.75 \mathrm{~g}(75 \%), 2.5 \mathrm{~g}(50 \%), 1.25 \mathrm{~g}(25 \%)$ and $0.75 \mathrm{~g}(12.5 \%)$ to cover a range. These accounted for substrate to inoculum ratios of $0.25,0.18,0.11,0.05$ and 0.03 , respectively, when combined with inoculum to a total mass of $25 \mathrm{~g}$.

These are listed in Table 2. The inoculum was mostly $99.666 \% \pm 0.012 \%$ water and $1 \mathrm{~mL}$ of inoculum was assumed to be approximately $1 \mathrm{~g}$. The $\mathrm{pH}$ of the inoculum was 8 . 
Table 2. Masses of fish offal, river tamarind and their combined masses placed in the bioreactor.

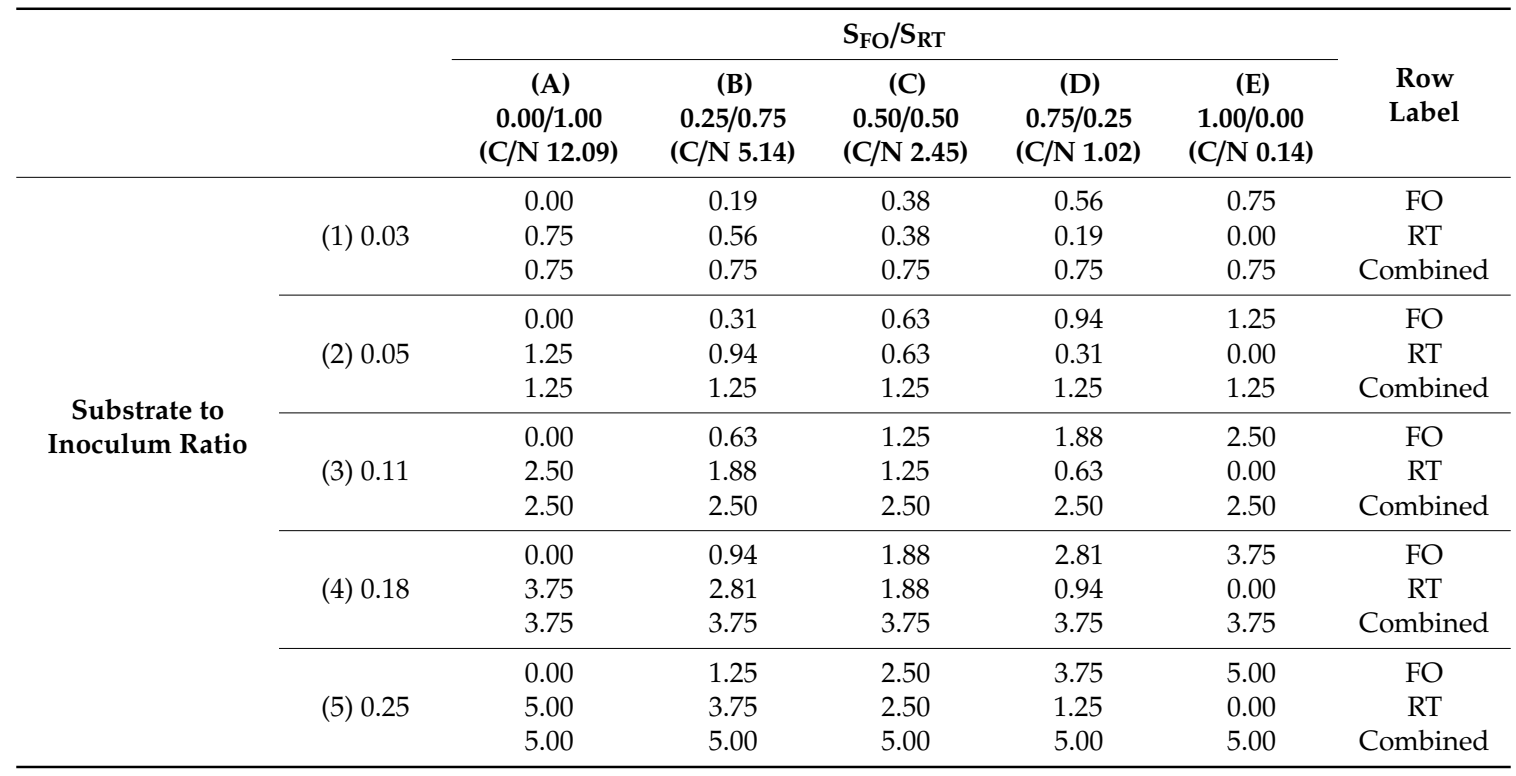

The second parameter is the substrate to substrate combinations. We used ratios of 0:1, 0.25:0.75, 0.5:0.5, 0.75:0.25 and 1:0 for $\mathrm{S}_{\mathrm{FO}} / \mathrm{S}_{\mathrm{RT}}$ as shown in Table 2. Table 2 also shows the actual masses of each substrate added to the bioreactors.

\subsection{Determination of Optimum Combination Using the Biochemical Methane Potential—BMP Test}

At the end of the experiment, the specific methane potential for each experimental condition was determined for the total mass of substrate used as well as the methane percentage in the biogas. The optimum substrate to substrate and substrate to inoculum concentration ratios were determined.

First, the methane concentrations produced were analyzed and the conditions which gave greater than $60 \%$ methane as a percentage of the biogas were selected for further analysis. Next, the conditions which gave the highest specific methane potentials (Table 3) among those conditions were selected to determine the overall optimum combination(s).

Table 3. Specific methane volume for each substrate combination. The river tamarind mass is decreasing while the fish offal mass is increasing, from left to right in the table. The substrate to inoculum ratio is increasing from top to bottom. $(n=3 \pm \mathrm{SD}) \mathrm{S}_{\mathrm{FO}} / \mathrm{S}_{\mathrm{RT}}$ is the substrate to inoculum ratio of fish offal to river tamarind.

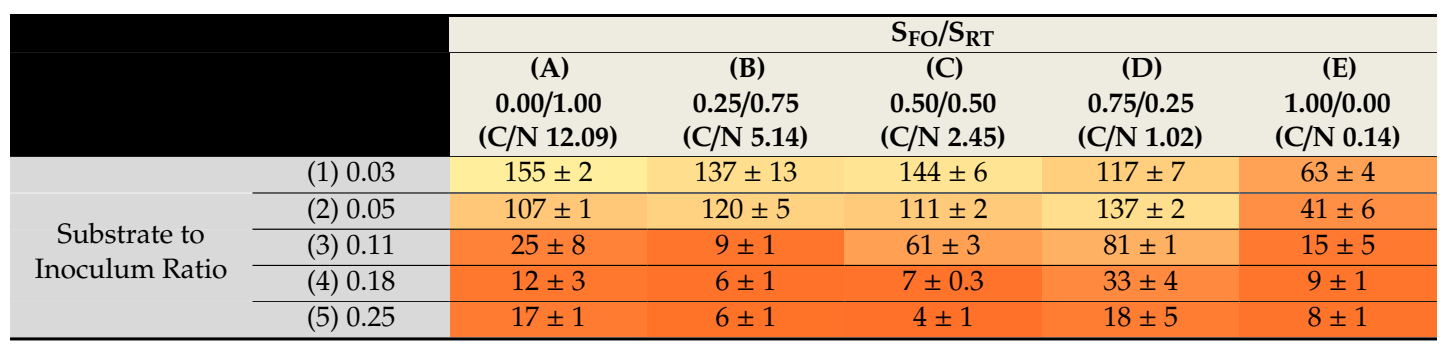

The color scale maps as shown in Tables 3-5 were generated using the "conditional formatting" feature in Microsoft Excel 2007, which produced a color gradient ranging from orange (low) to yellow (high), and the values were assigned an appropriate color depending on where they fell within this range. 
Table 4. Methane concentration as a percentage of the biogas for each substrate combination. The river tamarind mass decreases while the fish offal mass increases from left to right in the table. The substrate to inoculum ratio increases from top to bottom $(n=3 \pm S D)$, where $S_{\mathrm{FO}} / S_{\mathrm{RT}}$ is the substrate to inoculum ratio of fish offal to river tamarind.

\begin{tabular}{|c|c|c|c|c|c|c|}
\hline & \multicolumn{5}{|c|}{$\overline{\mathrm{S}_{\mathrm{FO}} / \mathrm{S}_{\mathrm{RT}}}$} \\
\hline & & (A) & (B) & (C) & (D) & (E) \\
\hline & & $0.00 / 1.00$ & $0.25 / 0.75$ & $0.50 / 0.50$ & $0.75 / 0.25$ & $1.00 / 0.00$ \\
\hline & & (C/N 12.09) & (C/N 5.14) & (C/N 2.45) & (C/N 1.02) & (C/N 0.14) \\
\hline \multirow{5}{*}{$\begin{array}{l}\text { Substrate to } \\
\text { Inoculum Ratio }\end{array}$} & (1) 0.03 & $84 \pm 2$ & $73 \pm 5$ & $76 \pm 4$ & $77 \pm 2$ & $76 \pm 1$ \\
\hline & (2) 0.05 & $87 \pm 0.5$ & $69 \pm 9$ & $72 \pm 5$ & $81 \pm 3$ & $75 \pm 5$ \\
\hline & (3) 0.11 & $59 \pm 19$ & $42 \pm 5$ & $62 \pm 1$ & $73 \pm 4$ & $62 \pm 9$ \\
\hline & (4) 0.18 & $48 \pm 8$ & $39 \pm 5$ & $48 \pm 3$ & $58 \pm 5$ & $56 \pm 3$ \\
\hline & (5) 0.25 & $48 \pm 3$ & $36 \pm 0.5$ & $31 \pm 4$ & $50 \pm 10$ & $55 \pm 8$ \\
\hline
\end{tabular}

Table 5. Final $\mathrm{pH}$ values for each condition. The river tamarind mass is decreasing while the fish offal mass is increasing, from left to right in the table. The substrate to inoculum ratio is increasing from top to bottom. (NmL/gFM). $(n=3 \pm \mathrm{SD})$.

\begin{tabular}{ccccccc} 
& & \multicolumn{5}{c}{$\mathbf{S}_{\mathbf{F O}} / \mathbf{S}_{\mathbf{R T}}$} \\
& & $\mathbf{( A )}$ & $\mathbf{( B )}$ & $\mathbf{( C )}$ & $\mathbf{( D )}$ & $\mathbf{( E )}$ \\
& & $\mathbf{0 . 0 0 / 1 . 0 0}$ & $\mathbf{0 . 2 5 / 0 . 7 5}$ & $\mathbf{0 . 5 0 / 0 . 5 0}$ & $\mathbf{0 . 7 5 / 0 . 2 5}$ & $\mathbf{1 . 0 0 / 0 . 0 0}$ \\
& & $\mathbf{( C / N ~ 1 2 . 0 9 )}$ & $\mathbf{( C / N ~ 5 . 1 4 )}$ & $\mathbf{( C / N ~ 2 . 4 5 )}$ & $\mathbf{( C / N ~ 1 . 0 2 )}$ & $\mathbf{( C / N ~ 0 . 1 4 )}$ \\
\cline { 2 - 7 } & $(1) 0.03$ & $7.27 \pm 0.38$ & $7.33 \pm 0.05$ & $7.14 \pm 0.03$ & $7.34 \pm 0.03$ & $7.42 \pm 0.07$ \\
\hline Substrate to & $(2) 0.05$ & $7.13 \pm 0.01$ & $7.59 \pm 0.26$ & $7.38 \pm 0.02$ & $7.35 \pm 0.02$ & $7.64 \pm 0.03$ \\
\cline { 2 - 7 } Inoculum Ratio & $(3) 0.11$ & $5.08 \pm 0.10$ & $5.22 \pm 0.3$ & $7.39 \pm 0.01$ & $7.65 \pm 0.11$ & $7.68 \pm 0.13$ \\
\cline { 2 - 7 } & $(4) 0.18$ & $5.01 \pm 0.02$ & $4.9 \pm 0.03$ & $5.74 \pm 0.35$ & $7.79 \pm 0.02$ & $7.66 \pm 0.24$ \\
\cline { 2 - 7 } & $(5) 0.25$ & $5.05 \pm 0.03$ & $4.96 \pm 0.04$ & $5.12 \pm 0.05$ & $7.18 \pm 0.11$ & $7.35 \pm 0.09$ \\
\hline
\end{tabular}

\section{Results}

\subsection{Determination of Optimum Substrate Combination: Analysis Methodology}

The cumulative specific methane volumes determined at the end of the biochemical methane potential test were placed in the Table (Table 3) and used to compare the effectiveness of each substrate to substrate ratio within the corresponding, overall substrate to inoculum ratio. The final methane concentrations in the biogas are also given (Table 4) to indicate the quality of the gas.

The major limitations to this type of co-digestion analysis are (1) the number of experimental setups which must be done, and (2) the number of reactors which must be sampled during one reading session, which can make the process laborious and tedious. In this matrix, 25 different combinations were done, each in triplicate, which totaled 75 individual bioreactors excluding the negative controls. This large experiment was possible because the size of the apparatus developed in our laboratory allowed for it. A small scale system like this or the Hohenheim bioreactor system is necessary in order to reasonably accommodate the large number of bioreactors required [15].

River tamarind was selected as the co-substrate for the digestion of the fish offal because it is high in carbohydrates and can provide an energy source for the microorganisms in the anaerobic digester. If the fish offal is the only feedstock, it must serve as both the carbon source for biosynthesis and growth and the energy source. If the fish offal serves as the energy source, then ammonia gets released which can inhibit the methanogenic pathway. By having a carbohydrate feedstock in the form of the river tamarind, there is a preferred energy source. As such, the amino acids in the high protein substrate (fish offal) are incorporated into the enzymes and other cellular structures of the cells, and are not biodegraded to release energy or ammonia as a by-product. Additionally, the river tamarind was chosen because it is a very resilient, common and fast growing tropical plant. Therefore, in terms of bioavailability, it would be relatively abundant for use on a practical scale. Additionally, it is high in cellulosic biomass which makes it suitable for co-digestion with a high protein substrate like the fish offal.

Each sector represents a triplicate set of bioreactors. All masses are given in grams. Substrate concentration is determined by substrate fresh matter mass $(\mathrm{g}) /$ inoculum mass $(\mathrm{g})$. Substrate to 
substrate ratio is determined by mass of substrate $A(g) /$ mass of substrate $B(g)$. $S_{F O} / S_{R T}$ is the substrate to substrate ratio of fish offal to river tamarind

\subsection{Effect of Blends on Specific Gas Production}

Based on Table 3, the conditions which gave the highest specific methane volumes were all combinations containing river tamarind and not exceeding an SIR of 0.05. All other combinations gave comparably low specific methane volumes. The general trend for all fish offal to river tamarind substrate to substrate $\left(\mathrm{S}_{\mathrm{FO}} / \mathrm{S}_{\mathrm{RT}}\right)$ combinations was that as the substrate to inoculum ratio increased, the specific methane potential decreased. There is one exception (Column D, 0.75 $\mathrm{S}_{\mathrm{FO}} 1: 0.25 \mathrm{~S}_{\mathrm{RT}}$ ), which has a relatively high specific methane potential at an SIR of 0.11 , suggesting that in this case the volatile fatty acids (VFA's) and ammonia production rates are balanced in a way that allows for a relatively good level of gas production at a higher SIR. The drop in methane yield with increasing SIR is a factor which has been attributed to the rapid accumulation of metabolic intermediates as a result of high substrate loads [1]. In the case of a high carbohydrate substrate, which in this case is the river tamarind, the problem is the accumulation of VFA's. The methanogens cannot convert the acetic acid formed from the VFA's into methane at the rate at which the acid-forming bacteria are producing these acids. These acids accumulate in the inoculum and cause a drop in its $\mathrm{pH}$. The methanogens cannot function optimally in acidic environments and methane production is reduced [16]. In the case of high protein substrates such as fish offal, ammonia produced from the biochemical degradation of the amino acids, which comprise the protein, can accumulate in the environment and inhibit the methanogens [16].

As shown in Table 3, substrate to inoculum ratios of greater than 0.05 resulted in reduced methane production, probably due to overloading conditions. When considering substrate combinations only at SIR's of 0.03 and 0.05 , at $100 \%$ tamarind $(\mathrm{C} / \mathrm{N} 12.09)$ the specific methane volume was greatest, while at $100 \%$ fish offal (C/N 0.14) the specific methane volume was markedly lower, by a factor of about 2.5 times. For all combinations of river tamarind and fish offal at these SIR's, the specific methane values were similar to the river tamarind alone, even at $75 \%$ fish offal (C/N 1.02). This suggests that even at a high fish offal load, a small amount of river tamarind can help boost degradation and possibly offset the impact of ammonia accumulation.

Organic compounds can be used by cells in two forms, either for biosynthesis in order to make cellular components such as nucleic acids, proteins and lipids, or as an energy source in order to produce ATP [17]. If there is sufficient carbohydrate (river tamarind), the amino acids released from the proteins (fish offal) won't be used as the main energy source but rather for biosynthesis, and so the nitrogen and carbon will get incorporated into the cellular components and minimal ammonia will be released. The other part to this statement is that if there is a metabolic option of using amino acids as opposed to carbohydrates for biosynthesis, the amino acids will be used preferentially.

This is due to very complex regulation and co-ordination of the biochemical processes carried out by the ecosystem of micro-organisms involved in biogas production. The organic material being used for ATP production ultimately forms acetate as it passes through the stages of anaerobic digestion [18]. The rate at which this acetate is formed is dependent not only on the initial quantity of organic material present, but also on the rate at which it can be converted to acetate, with some substrates being more biodegradable than others [19]. Since the biochemical process of biogas production is driven by enzymes produced by the bacterial consortium, the turnover rate of the bacteria and thus the enzymes they produce in order to carry out the methanogenesis process is also an important parameter in biogas production.

If the carbohydrates for ATP production become limiting (carbohydrates in this scenario drop below a certain level), then the proteins become both a carbon and an energy source. This results in a release of ammonia, which inhibits the process of methanogenesis [17]. It should also be noted that lipids are an excellent energy source but the anaerobic digestion of such materials causes an accumulation of long chain fatty acids, which can negatively impact the anaerobic digestion process [20,21]. There are several metabolic options, which are selected and regulated based on the specific needs of the microorganisms 
in the inoculum, the syntropic relationships of these microorganisms and the availability of the substrates to the microorganisms [17].

As seen from the results of the $\mathrm{pH}$ test (Table 5), at SIR's of 0.11-0.25 for combinations of 0:1 and 0.25:0.75 fish offal to river tamarind, and SIR's of 0.18-0.25 for the 50:50 combination of fish offal to river tamarind, the $\mathrm{pH}$ values were low, indicating acid build-up. These combinations resulted in low specific methane values. As mentioned earlier, high levels of organic carbon can result in high levels of VFA's being produced which can cause a reduction in $\mathrm{pH}$ and an inhibition of methanogens.

In all instances where there was good bioreactor performance, the $\mathrm{pH}$ was generally within the neutral range (around 7.0-7.5), as seen in Table 5. There were some instances where the $\mathrm{pH}$ was within the neutral range but bioreactor performance was poor. This is probably because while the ammonia produced did not cause the $\mathrm{pH}$ to shift far from the neutral range, it still had an adverse effect on the methanogens and directly inhibited them because the ammonium ion is also inhibitory and believed to directly inhibit the methane synthesizing enzyme complex [22,23]. Therefore, even at neutral $\mathrm{pH}$, an excess of ammonia in the form of the ammonium salt, which is toxic to methanogens, could result in low methane concentrations in biogas [23,24].

\section{3. $S_{F O} / S_{R T}$ : Substrate to Inoculum Ratio of Fish Offal to River Tamarind}

The overall best process configuration is the 50/50 fish offal to river tamarind substrate to substrate combination, at a substrate to inoculum ratio of 0.03 . At this substrate concentration the reactor is not overloaded with feedstock and so the turnover rate as it relates to volume of gas per unit mass of material is maximized. With respect to the substrate to substrate combinations, the consumption of fish offal and river tamarind is metabolically favorable for optimum functionality of the overall methanogenic biochemical pathway. The fish offal can suitably supply organic carbon and nitrogen in a form and at a rate that can facilitate the optimal rate of turnover and production of the enzymes needed to conduct the reactions, in addition to the molecular building blocks for cellular growth and division. The river tamarind can suitably supply the carbohydrates at a high enough rate that does not cause the cells to have to rely too heavily on the proteinaceous substrates as a source of energy, but at a low enough rate that there is no increase in volatile fatty acids. This gives the microbial consortium a main energy source and a main carbon source, and so the system as a whole operates optimally.

\subsection{Effect of Blends on Methane Concentration}

At substrate to inoculum ratios of 0.03 and 0.05 , all the substrate to substrate ratios tested gave biogas with a high methane content $(>70 \%)$, but at higher SIR the methane content decreased (Table 4 ). For combinations containing 50\% fish offal or less (C/N 2.45-12.09; [Table 4, A-C]), the methane concentrations dropped comparably lower than for those containing more than $50 \%$ fish offal (C/N 1.02-0.14; [Table 4, D and E]). This could be an indication of the inhibition of the methanogens caused by a decrease in $\mathrm{pH}$, which is consistent with the data shown in Table 5 . In fact, the low methane contents in sectors A3, A4, A5, B3, B4, B5, C4 and C5 are all associated with pH values in the acidic region, with the acid probably resulting from an accumulation of VFA's from the breakdown of the river tamarind at these high substrate loads.

For combinations containing more than $50 \%$ fish offal, there were no $\mathrm{pH}$ values in the acidic range and methane concentrations in the biogas were generally all greater than or equal to $50 \%$, regardless of substrate to inoculum ratio. High levels of fish offal would result in a release of ammonia (which is alkaline) and could cause an increase in $\mathrm{pH}$. As the substrate to inoculum ratio increased beyond 0.05 , the $\mathrm{pH}$ did not decrease. This is possibly due to the increasing ammonia levels counteracting the drop in $\mathrm{pH}$ caused by the increasing VFA's. However, the inhibitory effect caused by high protein substrates was evident from the considerably lower methane concentrations in the biogas (Table 4.) Specifically, while the methane concentrations did not drop below $50 \%$ for any of the conditions tested with high fish offal, the higher substrate to inoculum ratios $(>0.18)$ resulted in considerably lower values for the methane concentration in the biogas than the lower substrate to inoculum ratios. 
The high methane concentrations are an indicator of optimum activity, functionality and synergy of the microbial consortium as it relates to the biochemical conversion of the substrates to biogas.

\subsection{Potential Effects of Carbon and Nitrogen Balancing on Anaerobic Digester Functionality}

The high variability in the reported, suitable levels of organic carbon to nitrogen suggest a deeper underlying factor for optimizing biodegradation through substrate blending than simply balancing the carbon to nitrogen ratio $[8,25,26]$. Further evidence that optimization is not as simple as balancing the carbon to nitrogen ratio is seen in the specific methane volumes of the combinations A to D at SIR's of 0.03 and 0.05 . Given the large variation of the carbon to nitrogen ratio across this range of substrate to substrate combinations, the similarities of the specific methane volumes suggest that a better explanation as to the relationship between the $\mathrm{C} / \mathrm{N}$ ratio and anaerobic digester performance is needed.

Optimum co-digestion could result from highly organized metabolic control within the bioreactor in which ammonia is produced and consumed at an optimum rate. This could be considered most favorable for a thriving consortium of organisms that produce maximal methane from the substrates provided. In this instance, the river tamarind provides the energy source in the form of carbohydrates, which reduces or even removes the need for microorganisms to rely on the amino acids as an energy source. This allows them to be used mainly for biosynthesis.

Optimum co-digestion relates to substrate to substrate ratios, and not to an overall load of substrate in the inoculum, as overloading conditions can occur for all substrate types. However, as seen from the data, co-digestion could allow more substrate to be loaded by balancing the too-high levels of VFA and resulting low $\mathrm{pH}$ with high levels of counteracting ammonia. This is suggested by the relatively high percentage of methane and specific methane volume for $50 / 50$ and (better) $75 / 25 \mathrm{~S}_{\mathrm{FO}} / \mathrm{S}_{\mathrm{RT}}$ at SIR 0.11 , compared to tamarind alone or $25 / 75 \mathrm{~S}_{\mathrm{FO}} / \mathrm{S}_{\mathrm{RT}}$ (Table 4 .)

Proteinaceous substrates can be used as a source of energy, which ultimately results in the release of ammonia due to amino acid degradation [17]. Proteinaceous substrates can also be used as a source of nitrogen in which the amino acids can be directly sourced by the microorganisms to make enzymes and other proteins for their growth and survival. Additionally, ammonia that is released when amino acids are used as a carbon source serves as a nitrogen source for the biosynthesis of all N-containing cell constituents; hence, there is no net increase in ammonia. Therefore, the type of metabolic pathways being utilized plays a huge rule in the types of metabolic intermediates being formed. The influence of substrate types is an extremely important and interesting area to investigate, in order to better understand bioreactor performance and dynamics.

A better understanding of the biochemistry of substrate utilization could greatly improve anaerobic digestion. For example, a continuous anaerobic digester that is operating using grass only might see a reduction in performance over time, but the addition of fish offal, or some other proteinaceous substrate at certain intervals might help keep methane output high. This would result from adding extra amino acids to provide a nitrogen source as ammonia levels decrease over time due to loss of ammonia either in the effluent or as a gas. Because a nitrogen source is required for the biosynthesis of DNA, RNA and proteins-including the enzymes necessary for the biochemical process of methanogenesis which allows the bacterial consortium carrying out this process to survive-if there is a low level of available nitrogen, there will be slower growth rates.

The regulatory mechanisms built into the genetic profile of these microorganisms manage the conversion of these substrates in a manner so as to ensure survival of the consortium. Unless a severe situation arises such as a high substrate load which imbalances these regulatory mechanisms, the microorganisms have dynamic control over their biochemical conversion of these substrates. There is probably also control over the population of the consortium due to various symbiotic relationships, between groups of microorganisms and symbiotic regulation and management of their metabolic routes. 


\subsection{Comparative Studies}

In an article by Callaghan et. al, fish offal was digested with cattle slurry as the co-substrate, but this resulted in a decrease in the performance of the anaerobic digester. The authors attributed this decrease to long chain fatty acids generated from the oils in the fish and not necessarily to the levels of free ammonia [5]. Additionally, the fish offal was only increased to a $4 \%-6 \%$ mass to mass concentration of the cattle slurry, with inhibitory effects occurring from as low as $4 \%$. In our experiment, the fish offal was increased up to $75 \%$ mass to mass concentration, without any inhibitory effects occurring as a result of the high fish offal content. Inhibitory effects did occur if the substrate to inoculum ratio increased beyond 0.05 ( $5 \%$ substrate concentration). In the experiment performed by Callaghan's team, their substrate concentration was around $10 \%$, and this might have caused a decrease in reactor performance. Despite the methane values being provided in $\mathrm{m}^{3} \mathrm{~kg}^{-1} \mathrm{VS}$, it is difficult to do a direct comparison between the experiments because the experimental setups are different (batch-style vs. continuous digestion) but the basic principles of overloading should still apply.

In an article by Mshandete et al., co-digestion with sisal pulp showed an optimum blend at $25 \%$ fish offal to $75 \%$ sisal pulp, with a methane yield of $0.48 \mathrm{~m}^{3} \mathrm{~kg}^{-1} \mathrm{VS}$ and a 50:50 ratio producing $0.31 \mathrm{~m}^{3} \mathrm{~kg}^{-1} \mathrm{VS}$ (331 mL/goDM.) [8]. This can be somewhat directly compared with our 50:50 condition, which was an optimum condition and produced $330 \pm 14 \mathrm{NmL} /$ goDM. While the authors have not standardized their methane volumes to normal gas volumes, a comparison can be made on the assumption that their gas value does not deviate largely from the standard volume. If this is the case, the sisal pulp gives a very similar level of effect as a co-digestate to the river tamarind.

An article by $\mathrm{Xu}$ et al. used sugarcane bagasse as the co-substrate and found the 50:50 substrate to substrate ratio gave a specific methane yield of $339.1 \mathrm{~mL} / \mathrm{gVS}$ [27]. This again is directly comparable with our results, which gave a specific methane yield of $330 \pm 14 \mathrm{NmL} / \mathrm{goDM}$.

When comparing the three substrates used in the referred literature, the cattle slurry is expected to contain mostly biodegraded material, unlike the sisal pulp and cane bagasse which are left over fibrous materials from the processing industry. Sisal itself comes from the leaves of plants belonging to the agave family and pulp is a result of the paper processing industry. Sugarcane bagasse results after the cane has been pressed to remove the juice. The more cellulosic substrates were more effective co-substrates for the fish offal.

\subsection{Potential Real-World Applications of These Findings}

Based on the results of this study and the current situation in Barbados, there are several areas in which these findings can be applied for use in the real world. This section gives some of these potential areas.

(1) Waste management for Barbados and other SIDS is generally a big problem, especially if there are large/relatively large industries. This is because waste is generated quickly and dumped, which poses a serious problem as there is limited land space in these territories. Therefore, waste management is critical. Additionally, most SIDS rely on fossil fuel imports for energy generation, so energy security, availability and cost are also critical issues. As seen from the data, river tamarind can be used along with fish offal to produce a blend which is suitable for efficient biogas production. Therefore, the use of anaerobic co-digestion to treat fish offal and river tamarind is potentially of great value in certain territories such as Barbados where high levels of fish offal are generated and there is an abundance of river tamarind.

(2) This study was conducted in Barbados and can be directly applied in this island. It can also be applied more widely as the substrates fish offal and river tamarind are commonly found in the Caribbean and other tropical/subtropical regions. The fishing industry is one of the largest industries in Barbados, generating 1952.6 \pm 759.2 tons of fish per year and producing approximately 1000 tons of waste in the form of offal [28]. Additionally, the river tamarind is also being investigated for use as an energy crop in Barbados. Therefore, the results of this test can be applied to the current situation to help manage the large amounts of waste generated from the fishing industry through anaerobic 
co-digestion, increasing the practicality of the study. Furthermore, numerous other territories that have strong fishing industries and generate large amounts of fish offal can utilize this information.

(3) The biogas produced from some of the anaerobic digesters utilizing fish offal could be compressed and used as a fuel for fishing boats. The boats could be equipped with biogas conversion kits which would allow the boat engines to run using compressed biomethane. This compressed biomethane could be used as a replacement for diesel, which is now currently used as an energy source for fishing boats. Furthermore, the efficiency of biogas production from the anaerobic digesters could be increased through co-digestion with river tamarind as seen from our data.

(4) With the implementation of biogas plants, laws could then be put in place to put fines on people who still continue to dump fish offal at the landfill when there is another viable option. Of course, this will only be applicable once biogas production becomes mainstream.

(5) River tamarind as a part of landscaping waste can be used specifically in anaerobic digesters which mainly process fish offal. Additionally, even though river tamarind is generally considered an unwanted crop, there are some soil remediation projects which seek to use river tamarind as a crop to introduce nitrogen into the soil. This intercropping method would mean that the river tamarind would need to be harvested every so often and could be used in anaerobic digesters which process fish offal.

\subsection{Practical Implications of the Study and Future Research}

This study evaluated the use of river tamarind and fish offal (from the dolphin fish) as potential substrates for anaerobic co-digestion and determined an optimum blend. However, there are several other plant-based biomass sources which can also potentially serve as co-digestion substrates. These include various grasses found around the island, several of which were investigated in one of our previous studies [29]. These can also be tested in co-digestion with fish offal and the yields can be compared to co-digestion with the river tamarind.

The correlation between laboratory scale results and large scale anaerobic co-digestion of these substrates should also be investigated. This can help to determine the efficiency of gas production as plant size increases, which can further tie into real world applications of the results.

Additionally, upon investigation of the mixture for biogas production on a larger scale, the sludge produced could potentially be high in ammonia caused from the breakdown of the fish offal. This can be studied for its use as a fertilizer in soil technology or agronomy projects.

This study suggests that some strong regulation of biochemical pathways is at work which relates to ammonia production from high protein substrates. The selection of amino acids from proteins either as a source of organic carbon (which results in release of ammonia) or to be directly incorporated into proteins (serving as both carbon and nitrogen source) and how this varies depending on the level of organic carbon in the digester, needs to be properly evaluated from a biochemical perspective. A more in-depth understanding of the biochemistry under these conditions can greatly improve the understanding of anaerobic co-digestion and assist in optimization of biogas production.

\section{Conclusions}

Co-digestion of substrates aids in nutrient balance and can increase the overall methane yield or rate of methane production from a bioreactor.

In this experiment, a total of 25 substrate combinations were tested and it was determined that the river tamarind alone had the potential to give a high yield of methane $(155 \pm 2 \mathrm{NmL} / \mathrm{gFM}$; $355 \pm 5 \mathrm{NmL} / \mathrm{goDM})$. The methane potential of the fish offal was very low by comparison $(63 \pm 4 \mathrm{NmL} / \mathrm{gFM} ; 317 \pm 20 \mathrm{NmL} / \mathrm{goDM})$ at the mixing ratios that gave the highest yield for the respective substrates, which were SIR's of 0.03 in both cases.

In terms of co-digestion performance, there was an improvement on the overall yield per total mass of substrate loaded when compared to the fish offal alone, even in situations where there was still a relatively large contribution of fish to the feedstock mass $(75 \%)$. 
However, the condition which gave the best output was that of $50 \%$ fish offal and $50 \%$ river tamarind $(144 \pm 6 \mathrm{NmL} / \mathrm{gFM} ; 330 \pm 14 \mathrm{NmL} / \mathrm{goDM})$ at a substrate to inoculum ratio of 0.03 . The gas also reached good quality at $76 \% \pm 4 \%$ methane. These results are very significant because this information can then be implemented in a larger scale application. Additionally, by determining the most suitable configuration on a laboratory scale, this removes the trial and error stage of determining the optimum mixing ratios on a larger scale. Additionally, being able to efficiently process such a high mass of fish offal as a result of co-digestion with the river tamarind, provides an effective method of anaerobically digesting large quantities of this proteinaceous waste.

Taking standard deviations into consideration, some of the other combinations could be considered to be just as good, such as $25 \%$ to $75 \%$ fish offal to river tamarind, at both 0.03 and 0.05 substrate to inoculum ratios, and $75 \%$ to $25 \%$ fish offal to river tamarind and a substrate to inoculum ratio of 0.05 .

Author Contributions: Conceptualization, N.H.; data curation, N.H.; methodology, N.H.; project administration, M.M.-M.; supervision, J.B. and S.L.S.; writing—original draft, N.H.; writing-review \& editing, S.L.S. All authors have read and agreed to the published version of the manuscript.

Funding: This research received no external funding.

Acknowledgments: The authors would like to thank the anonymous reviewers for their comments and suggestions, which have helped to improve the quality of this paper.

Conflicts of Interest: The authors declare no conflict of interest.

$\begin{array}{ll}\text { Abbreviations } \\ (\mathrm{C} / \mathrm{N}) & \text { Carbon to nitrogen ratio } \\ \mathrm{NmL} / \mathrm{gFM} & \text { Normalized volume of methane gas in mL per gram of fresh matter } \\ \mathrm{DM} & \text { Dry matter } \\ \text { oDM } & \text { Organic dry matter } \\ \text { TOC } & \text { Total organic carbon } \\ \mathrm{BMP} & \text { Test biochemical methane potential test } \\ \text { SFO } & \text { Substrate fish offal } \\ \text { SRT } & \text { Substrate river tamarind } \\ \mathrm{S}_{\mathrm{FO}} / \mathrm{S}_{\mathrm{RT}} & \text { Fish offal to river tamarind substrate to substrate ratio } \\ \text { SIDS } & \text { Small Island Developing States }\end{array}$

\section{References}

1. Dechrugsa, S.; Kantachote, D.; Chaiprapat, S. Effects of inoculum to substrate ratio, substrate mix ratio and inoculum source on batch co-digestion of grass and pig manure. Bioresour. Technol. 2013, 146, 101-108. [CrossRef] [PubMed]

2. Kameswari, K.S.B.; Kalyanaraman, C.; Subramanian, P.; Thanasekaran, K. Optimization of inoculum to substrate ratio for bio-energy generation in co-digestion of tannery solid wastes. Clean Technol. Environ. Policy 2012, 14, 241-250. [CrossRef]

3. Álvarez, J.A.; Otero, L.; Lema, J.M. A methodology for optimising feed composition for anaerobic co-digestion of agro-industrial wastes. Bioresour. Technol. 2010, 101, 1153-1158. [CrossRef]

4. Haider, M.R.; Sheikh, Z.; Yousaf, S.; Malik, R.N.; Visvanathan, C. Effect of mixing ratio of food waste and rice husk co-digestion and substrate to inoculum ratio on biogas production. Bioresour. Technol. 2015, 190, 451-457. [CrossRef] [PubMed]

5. Callaghan, F.J.; Wase, D.A.J.; Thayanithy, K.; Forster, C.F. An Examination of the Continuous Anaerobic Co-Digestion of Cattle Slurry and Fish Offal. Process Saf. Environ. Prot. 1998, 76, 224-228. [CrossRef]

6. Miron, Y.; Zeeman, G.; van Lierm, J.B.; Lettinga, G. The role of sludge retention time in the hydrolysis and acidification of lipids, carbohydrates and proteins during digestion of primary sludge in CSTR systems. Water Res. 2000, 34, 1705-1713. [CrossRef]

7. Molinuevo-Salces, B.; García-González, M.C.; González-Fernández, C.; Cuetos, M.J.; Morán, A.; Gómez, X. Anaerobic co-digestion of livestock wastes with vegetable processing wastes: A statistical analysis. Bioresour. Technol. 2010, 101, 9479-9485. [CrossRef] 
8. Mshandete, A.; Kivaisi, A.; Rubindamayugi, M.; Mattiasson, B. Anaerobic batch co-digestion of sisal pulp and fish wastes. Bioresour. Technol. 2004, 95, 19-24. [CrossRef]

9. United and Nations. Small Island Developing States/Small Islands Big(ger) Stakes; One United Nations Plaza, Room 1210: New York, NY, USA, 2011.

10. Helffrich, D.; Oechsner, H. The Hohenheim Biogas Yield Test. Landtechnik 2003, 58, 148-149.

11. VDI 4630-Fermentation of Organic Materials. Characterisation of the Substrate Sampling, Collection of Material Data, Fermentation Tests. Available online: https://standards.globalspec.com/std/10052171/VDI\% 204630 (accessed on 3 August 2020).

12. Heanes, D.L. Determination of total organic-C in soils by an improved chromic acid digestion and spectrophotometric procedure. Commun. Soil Sci. Plant Anal. 1984, 15, 10-11. [CrossRef]

13. Walkley, A.; Black, I.A. An examination of the Degtjareff method for determining soil organic matter, and a proposed modification of the chromic acid titration method. Soil Sci. 1934, 37, 29-38. [CrossRef]

14. Mæhre, H.K.; Dalheim, L.; Edvinsen, G.K.; Elvevoll, E.O.; Jensen, I.-J. Protein Determination-Method Matters. Foods 2018, 7, 2-11.

15. Holder, N.; Mota-Meira, M.; Born, J.; Sutrina, S.L. New Small Scale Bioreactor System for the Determination of the Biochemical Methane Potential. Waste Biomass Valorization 2017, 10, 1083-1090. [CrossRef]

16. Parkin, G.F.; Owen, W.F. Fundamental sofan aerobic digestion of waste water sludges. J. Environ. Eng. 1986, 112, 867-868. [CrossRef]

17. Berg, J.M.; Tymoczko, J.L.; Stryer, L. Biochemistry, 5th ed.; W. H. Freeman and Company: New York, NY, USA, 2001.

18. Zupančič, G.D.; Grilc, V. Anaerobic treatment and biogas production from organic waste. In Management of Organic Waste; W. H. Freeman and Company: New York, NY, USA, 2002.

19. Biarnes, M. Biomass to Biogas-Anaerobig Digestion. 2013. Available online: https://www.e-inst.com/ training/biomass-to-biogas/ (accessed on 30 October 2018).

20. Eiroa, M.; Costa, J.C.; Alves, M.M.; Kennes, C.; Veiga, M.C. Evaluation of the biomethane potential of solid fish waste. Waste Manag. 2012, 32, 1347-1352. [CrossRef]

21. Kafle, G.K.; Kim, S.H.; Sung, K.I. Ensiling of fish industry waste for biogas production: A lab scale evaluation of biochemical methane potential (BMP) and kinetics. Bioresour. Technol. 2013, 127, 326-336. [CrossRef]

22. Yenigün, O.; Demirel, B. Ammonia inhibition in anaerobic digestion: A review. Process Biochem. 2013, 48, 901-911. [CrossRef]

23. Kayhanian, M. Ammonia Inhibition in High-Solids Biogasification: An Overview and Practical Solution. Environ. Technol. 2010, 20, 355-365. [CrossRef]

24. Webb, A.R.; Hawkes, F.R. The anaerobic digestion of poultry manure: Variation ofgas yield with influent concentration and ammonium-nitrogen levels. Agric. Wastes 1985, 14, 135-156. [CrossRef]

25. Wang, X.; Lu, X.; Li, F.; Yang, G. Effects of Temperature and Carbon-Nitrogen (C/N) Ratio on the Performance of Anaerobic Co-Digestion of Dairy Manure, Chicken Manure and Rice Straw: Focusing on Ammonia Inhibition. PLoS ONE 2014, 9, e97265. [CrossRef]

26. Chen, Y.; Cheng, J.J.; Creamer, K.S. Inhibition of anaerobic digestion process: A review. Bioresour. Technol. 2007, 99, 4044-4046. [CrossRef] [PubMed]

27. Xu, J.; Mustafa, A.M.; Sheng, K. Effects of inoculum to substrate and co-digestion with bagasse on biogas production of fish waste. Environ. Technol. 2016, 38, 2517-2522. [CrossRef] [PubMed]

28. Research \& Planning Unit. Barbados Economic and Social Report; Ministry of Finance, Economic Affairs and Investment (MFEI): St. Michael, Barbados, 2016.

29. Holder, N.; Persaud, A.; Mota-Meira, M.; Born, J.; Sutrina, S.L. The Influence of Physico-Chemical Parameters, Substrate Concentration \& Species Variations on the Biochemical Methane Production Rates of Ten Tropical/Subtropical Grasses. Biofuels Bioprod. Biorefin. 2018. [CrossRef]

(C) 2020 by the authors. Licensee MDPI, Basel, Switzerland. This article is an open access article distributed under the terms and conditions of the Creative Commons Attribution (CC BY) license (http://creativecommons.org/licenses/by/4.0/). 